\title{
THE FACTORS WHICH DETERMINE THE LOCAL INCIDENCE OF FATAL INFANTILE DIARRHOEA.
}

\author{
By H. MEREDITH RICHARDS, M.D. (Lond.),
} Medical Officer of Health of Croydon.

THE various problems of infantile mortality are not only supremely interesting to the medical officer of health, but, with the continued decline in the birth rate, are calculated to assume even greater practical importance in the near future. Of these problems none is more in need of solution than the exact etiology of infantile diarrhoea.

It is moreover one which the writer has repeatedly had to investigate during the last seven years under such diverse conditions as obtain in a small manufacturing town in North Derbyshire and in a large residential borough in Surrey.

In Chesterfield, during the years 1896 to 1899 , the infantile death rate amounted to 195 per 1,000 births, while the deaths under one year from diarrhoeal diseases ${ }^{1}$ equalled $54 \cdot 4$ per 1,000 births, ranging from 44 in 1896 to $83 \cdot 1$ in 1897.

In Croydon on the other hand the infantile mortality rate is considerably lower, but there are and have been indications that this rate is hardly as satisfactory as might have been expected in such an exceptionally healthy town. Indeed while the general death rate maintains its low level there appears to be a tendency for the infantile mortality figures to approximate more and more closely to those for London and for England and Wales.

For instance an examination of the figures for the last twenty-two years gives the following results:

TABLE I.

$\begin{array}{cccc}\text { Years } & \text { Croydon } & \text { London } & \text { England and Wales } \\ 1881-1890 & 120 & 152 & 142 \\ 1891-1900 & 139 & 160 & 154 \\ 1901 & 140 & 149 & 151 \\ 1902 & 133 & 141 & 133\end{array}$

1 Throughout this paper the term "diarrhoeal diseases" will include deaths from diarrhoea, zymotic enteritis, gastro-enteritis, and enteritis, i.e. schedules 10, 11, and 107 of the Society of Medical Officers of Health. 
While my predecessor's reports for the years 1883 to 1899 and my own statistics for the years 1900 to 1902 suggest that, as far as the assigned causes of death are to be relied on, diarrhoeal diseases bulk more largely than formerly in the mortality tables.

TABLE II.

Infantile Mortality in Croydon during the last twenty years.

$\begin{array}{cccc}\text { Total Infantile } & \begin{array}{c}\text { Mortality } \\ \text { per 1000 Births }\end{array} & \begin{array}{c}\text { Deaths under 1 from } \\ \text { Diarhoea and Enteritis } \\ \text { per 1000 Births }\end{array} & \begin{array}{c}\text { Infantile Mortality } \\ \text { from other causes } \\ \text { than Diarrhoea }\end{array} \\ 1883-1887 & 118 & 16 & 102 \\ 1888-1892 & 116 & 10 & 106 \\ 1893-1897 & 142 & 25 & 117 \\ 1898-1902 & 143 & 38 & 105\end{array}$

Before, however, suggesting remedial measures in Croydon, it was decided to collect as much information as possible as to the local distribution and ascertained antecedents of all cases of fatal diarrhoea in infants under one year of age.

The local facts are based on a careful examination of all the deaths under one year in Croydon during the ten years 1893 to 1902, and on special enquiries into deaths from diarrhoeal diseases in Croydon during 1900 to 1902 , amplified by similar information collected in Chesterfield during the years 1896 to 1899 .

In order to measure the local incidence with exactness, attention has been confined (unless otherwise stated) to deaths under one year, as these can be accurately measured in terms of the total annual or decennial births. In the following pages an attempt has been made to apply these facts to current etiological hypotheses, with a view of ascertaining how far they could account for the local phenomena. The results may be of some general interest because, as will be shown later on, Croydon is a borough with a comparatively large acreage (9012 acres) divided into sub-districts which differ widely in the geological character of the soil, in the physiographical conditions of the surface, and in the social status of the inhabitants.

\section{What is known as to Etiology of Diarrhoea?}

Physicians, bacteriologists, and epidemiologists have all made valuable and lengthy contributions to the subject. Their most important suggestions will be considered in detail later; but briefly stated, physicians are agreed that fatal diarrhoea affects infants brought up by 
hand rather than those which are breast-fed, and attribute the bulk of it to want of care or knowledge in the preparation of infants' food.

Bacteriologists on the other hand do not for the most part speak with any certain voice. Streptococci, Bacillus sporogenes enteritidis, Bacillus proteus have all been described ${ }^{1}$ as causes of epidemic diarrhoea. More recently Prof. Delépine ${ }^{2}$ has brought forward further reasons for suspecting members of the coli group as the most common cause of summer diarrhoea.

Epidemiologists appear to have proved that diarrhoea mortality is most frequent among the poor; is associated with urban conditions; is mainly confined to the third quarter of the year; is more common in hot, dry summers than when those periods of the year are cool and wet; is probably more common where the soil is polluted with organic matter and where the physical conditions (such as permeability and surface slope) do not lend themselves to natural cleansing by showers of rain.

Yet in spite of all this accumulated labour it cannot be said that our knowledge is sufficiently precise to afford sure guidance in the selection of remedial measures.

\section{Need for detailed information as to antecedent processes.}

In a recent address ${ }^{3}$ Prof. Allbutt declared that he was sick of diseases and wanted to "know processes and origins." Those who are engaged in the practice of hygiene must often have re-echoed this wish; for it is to the fuller understanding of processes that we must look for guidance in formulating preventive measures. "Processes" indeed are frequently of far greater importance than even "origins," as has recently been demonstrated in the case of malaria and yellow fever. For there can be no doubt that it is the recognition of the part played by mosquitoes in these diseases that is destined to produce practical results. Similarly the discovery of the particular germ or germs concerned in the production of diarrhoea is hardly likely to be fruitful unless the precise avenues of infection are clearly demonstrated.

"Diarrhoea," it must also be remembered, is simply the name of an obvious symptom which may result from such diverse causes as a purgative, nervous shock, mechanical irritation, or from some general infection. Even the symptom-complex described by Ballard ${ }^{4}$ in his

1 Gordon, Practitioner, August 1902.

3 Lancet, 1903, I., p. 645.
2 This Journal, 1903, Vol. III. p. 68.

${ }^{4}$ L. G. B. Supplement 1889. 
classical report on diarrhoea does not necessarily predicate etiological identity even in cases which appear to the clinician to be precisely similar; and summer diarrhoea, even if proved to be an infective disease, may, however uniform its other antecedents, be as diverse in its bacteriology as ulcerative endocarditis or other forms of pyaemia which result from the invasion of the body by various pyogenic organisms. In any case it seems not unlikely that, as in the case of typhoid fever and polluted water, useful results may be arrived at by purely epidemiological and clinical methods, and that premature dependence on bacteriological inferences may delay the advent of those approximations to the truth which we are all anxious to reach.

It must also be understood that, though the observations are discussed under headings, the various suggested causes are not mutually exclusive, and that though each fatal case of diarrhoea has its own special antecedents there is no reason why the antecedents should be the same in each instance.

\section{What is meant by Diarrhoeal Diseases?}

At the onset one is met with difficulties of nomenclature and classification.

Should we adopt the classification of the Registrar-General and exclude from consideration all deaths ascribed to enteritis and gastroenteritis (i.e. Schedule 107 of the Society of Medical Officers of Health)? After careful consideration it seemed unwise to do so. It is true the term "enteritis" probably includes a certain number of deaths that differ in their antecedents from the acute form of diarrhoea which is variously known as "summer diarrhoea," "zymotic enteritis," or "epidemic diarrhoea." Yet there can be no doubt that the majority of cases of "enteritis" differ neither in causation nor in symptoms from the other group. Both "diarrhoea" and "enteritis" are summer diseases, as may be seen from Charts I. and II., and from Table III., and the balance of evidence is in favour of treating them in the aggregate and so avoiding the difficulty that might arise from variations which make it so difficult to institute comparisons between different towns and districts.

The following is a summary of the deaths under 1 year from diarrhoea and enteritis in Croydon during the last decennium. 
TABLE III.

$\begin{array}{cccc}\text { Yoar } & \begin{array}{c}\text { Number of } \\ \text { Births }\end{array} & \begin{array}{c}\text { Deaths under 1 year } \\ \text { from Diarrhoea } \\ \text { and Enteritis }\end{array} & \begin{array}{c}\text { Deaths during } \\ \text { 3rd quarter from } \\ \text { Diarrhoea and Enteritis }\end{array} \\ 1893 & 2852 & 82 & 65 \\ 1894 & 2805 & 20 & 15 \\ 1895 & 2906 & 77 & 59 \\ 1896 & 2964 & 65 & 54 \\ 1897 & 3034 & 113 & 102 \\ 1898 & 3150 & 161 & 141 \\ 1899 & 3204 & 153 & 134 \\ 1900 & 3270 & 94 & 70 \\ 1901 & 3578 & 137 & 123 \\ 1902 & 3576 & 72 & 56 \\ \text { Total for } 10 \text { years } & 31,339 & 974 & 819\end{array}$

Average Diarrhoeal Rate $31 \cdot 1$ per 1000 births.

" $" 26 \cdot 1, \quad, \quad$ in 3rd quarter.

Method of Feeding.

During the last three years enquiries have been made into all deaths under one year of age. In many instances full information could not be elicited; but in 1,008 cases the replies obtained by the Health Visitors were sufficiently full to admit of tabulation. In considering the relation of various methods of feeding to diarrhoeal diseases, all deaths under one week were omitted as they would obviously be of little value. 253 infants aged one week to one year dying from diarrhoea or enteritis were found to have been fed in the following way, and for the sake of comparison are placed in parallel columns with 313 deaths from respiratory and other diseases not likely to be associated with food infection.

\section{TABLE IV.}

\begin{tabular}{|c|c|c|c|c|}
\hline \multirow{3}{*}{$\begin{array}{l}\text { Number investigated } \\
\text { Age in months }\end{array}$} & \multicolumn{2}{|c|}{$\begin{array}{l}\text { Respiratory Dis., } \\
\text { Overlain, Measles, } \\
\text { Whooping Cough, } \\
\text { "Other" Diseases }\end{array}$} & \multicolumn{2}{|c|}{$\begin{array}{c}\text { Diarrhoea and } \\
\text { Enteritis }\end{array}$} \\
\hline & \multicolumn{2}{|c|}{313} & \multicolumn{2}{|c|}{253} \\
\hline & $\widehat{0-6}$ & $6-12$ & $0-6$ & $6-12$ \\
\hline Breast alone & 55 p.c. & 43 p.c. & 14 p.c. & 11 p.c. \\
\hline Breast and food & 1 & 1 & & 2 \\
\hline Breast and cows' milk & 3 & - & 1 & - \\
\hline Condensed milk & 17, & 21, & 33, & 29, \\
\hline Other prepared foods & $1 "$ & 3, & 3 & 4, \\
\hline Cows' milk & 23, & 32, & 48, & 54, \\
\hline
\end{tabular}

The results are sufficiently striking, especially when one confines one's attention to the proportion of infants fed by the breast alone in 
the two classes. It is quite true that the mere fact that only 14 and 11 per cent. of infants dying from diarrhoeal diseases were breast-fed does not prove that diarrhoea results from food infection, as these may be the average methods of feeding infants in the district. In default of accurate figures as to the method employed in the case of surviving infants in Croydon comparison may not unfairly be made with the replies received in the case of respiratory and other diseases not likely, on a priori grounds, to be associated with errors in diet.

If we assume that the method of feeding in these cases is the average-then out of 10,000 infants:

\begin{tabular}{|c|c|c|c|c|c|}
\hline \multicolumn{6}{|c|}{5500 are breast-fed alone } \\
\hline 100 & have & ood & , & ", & ", \\
\hline 300 & , & breast and cows' milk & $\mathrm{k}$, & " & \\
\hline 1700 & , & condensed milk & " & $"$ & $"$ \\
\hline 100 & , & other prepared foods & 8, & , & 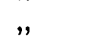 \\
\hline 2300 &, & cows' milk & ," & , & , \\
\hline
\end{tabular}

Now during the same period there were 191 deaths under six months from diarrhoea and enteritis among 10,424 births or 183 for 10,000 births.

And from the third column of Table IV. it will be seen that these 183 deaths from diarrhoea under six months were distributed as follows :

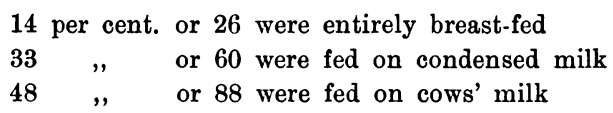

During the first six months of life the death rate from diarrhoea was therefore in round numbers

$$
\begin{aligned}
& 5 \text { per } 1000 \text { among the entirely breast-fed } \\
& 35 \quad " \quad \text { in those fed on condensed milk } \\
& 38 \quad " \quad \text { in those fed on cows' milk }
\end{aligned}
$$

As a further proof of the relation of methods of feeding to diarrhoeal diseases, the following figures may be quoted. In 1898, 372 deaths of infants in Chesterfield were investigated, and similar enquiries were made in the case of 408 surviving infants with the following results, as regards infants under six months, expressed in percentages.

$\begin{array}{lcc}\text { Breast-fed only } & \begin{array}{c}\text { Survivors } \\ \text { per cent. }\end{array} & \begin{array}{c}\text { Deaths from } \\ \text { Diarrhoea per cent. }\end{array} \\ \text { Breast and food } & 42 & 11 \\ \text { Milk and foods } & 42 & 22 \\ & 16 & 67\end{array}$


In other words, while only 16 per cent. of the surviving children were entirely subjected to the risks of hand-feeding, no less than 67 per cent. of those dying from diarrhoeal diseases were so subjected.

These figures are amply confirmed by those of other observers. Those given by Dr Newsholme (Trans. Epidemiol. Society, Vol. xxi.) are particularly corroborative. In 191 cases of fatal diarrhoea in Brighton it was found that the method of feeding was as follows:

$$
\begin{array}{lc}
\text { Breast } & 9 \cdot 4 \text { per cent. } \\
\text { Condensed milk } 44, ",
\end{array}
$$

From similar enquiries, Dr Hope finds that if 1000 breast-fed infants under 3 months of age have to encounter the risks of summer diarrhoea in Liverpool, then 20 will succumb. In the case of 1000 hand-fed children 300 would die from that cause. (Ann. Rep. Liverpool, 1900.)

There can therefore be no reasonable doubt that hand-feeding is a common antecedent of fatal diarrhoea in infants, and that those who are hand-fed are much more likely to suffer from diarrhoea than are those who receive the food which nature intended for them.

\section{How does hand-feeding tend to produce fatal diarrhoea?}

It is necessary however to pursue the enquiry a step further and ascertain the exact processes which tend to make hand-feeding so hazardous. First it might be suggested that hand-fed infants are more weakly than those brought up on the breast and therefore more prone to fall victims to any debilitating complaint. But though breastfeeding is always desirable in the interests of the infant, there can be no doubt that hand-feeding may be perfectly successful if judiciously supervised, and, as Ballard pointed out (loc. cit. p. 45), summer diarrhoea does not make its first fatal swoop upon the weakliest children nor confine its attention to the delicate.

Next it might be argued that the poison of diarrhoea is introduced into the homes of the poor by means of milk, and when one considers how very unsatisfactory are the methods of the average dairyman there is much to be said for this hypothesis as has so ably been urged by Prof. Delépine (loc. cit.). According to this writer milk which is contaminated with faecal matter at the farm developes toxicity from being kept too long in hot weather. Summer diarrhoea he suggests is strictly analogous to the ordinary forms of food poisoning which have been shown by various bacteriologists to be due to infection with 
Gärtner's bacillus or allied members of the coli group. This view is supported by the extremely interesting and valuable observations made on samples of milk collected in various parts of the country during the last ten years and examined by subcutaneous injection into guinea-pigs. It need hardly be pointed out that this hypothesis has the merit of simplicity and, if adopted, would make the selection and direction of preventive measures a comparatively easy matter. All would be relieved to find that diarrhoea was dependent on the intestines of the cow and not on some mysterious change in the bowels of the earth. For, if that were so, adequate control of the milk supply would solve the chief difficulty.

But does Professor Delépine's hypothesis explain the facts? In the first place is diarrhoea really analogous to such epidemics of food poisoning as that which occurred at Derby in September 1902? Now from an examination of the Local Government Board reports and the recent medical journals it would appear that the seasonal incidence is very different. For excluding cases due to tinned food I have been able to find records of some 22 cases of food-poisoning. These occurred at the following seasons :

$\begin{array}{llll}\text { First quarter } & 5 & \text { Third quarter } & 6 \\ \text { Second , } & 6 & \text { Fourth }, & 5\end{array}$

They therefore differ in the seasonal incidence from fatal diarrhoea, which is practically confined to the third quarter of the year, as is well illustrated in the accompanying charts. Nor do diarrhoea deaths ordinarily occur to any great extent in groups such as those which mark other food epidemics. The interesting epidemic referred to by Professor Delépine (loc. cit., p. 74) is entirely exceptional. Indeed it is because it is exceptional both in season and in grouping that it stands out so clearly from what one sees every summer during the diarrhoea season. Nor must the experiments with guinea-pigs be accepted for more than they are worth. If we are intended to infer that, because 61 per cent. of the milk reaching Manchester from a distance is toxic to guinea-pigs, it is therefore toxic to infants in the sense that the Derby pork-pies were to adults ; then it can only be suggested that diarrhoea ought to be even more general and fatal than it is at present. If on the other hand we are to assume that the milk proved toxic to guinea-pigs simply because ordinary faecal contamination was rendered active by the milk being kept too long in hot weather; then the incidence of 
summer diarrhoea should vary with the temperature of the air and with the distance that milk has to travel before reaching the consumers.

With regard to the temperature of the air Ballard pointed out that "the influence thus exerted is not a direct infuence, except in so far as it affects also infant mortality from all causes;" whereas the figures quoted by Prof. Delépine in Tables IV. and V. (loc. cit. p. 83) show that the mean temperature of the air had a very direct effect on milk judged by its action on guinea-pigs.

The curves for Croydon however do not show that diarrhoea fatality varies with the temperature of the air. It will be seen, for instance, that in 1902 the highest mean temperature of the air was reached in the 26th week, while there was no prevalence of fatal diarrhoea until the 33rd week. In 1901, again, diarrhoea became epidemic as the mean temperature was falling.

In 1898 the temperature-curve corresponded fairly well with the diarrhoea fatality; but 1898 was an exceptionally dry summer. It should also be noted that diarrhoea deaths did not occur until some weeks after the mean temperature had reached $55^{\circ}$ Fahr., the point at which marked toxic effects should be produced by milk coming from a distance according to Prof. Delépine's experiments. In 1894 diarrhoea was practically absent though the mean temperature was above $55^{\circ} \mathrm{Fahr}$. for fourteen weeks.

Similarly with regard to the time factor, it is a matter of common knowledge that London does not suffer to any extreme degree from diarrhoea mortality though there is probably no town in the country which draws its milk from a greater distance.

Nor did an analysis of the method of feeding of the fatal cases of diarrhoea lend the least support to the suggestion that such diarrhoea was consequent on the ingestion of milk which came from a great distance. For an examination of Tables III. and IV. (p. 329), shows that a not inconsiderable number of infants dying from diarrhoea and enteritis were breast-fed, while only a little more than half were receiving fresh cows' milk. Nor would it seem probable that condensed milk is primarily infective. In none of the eight samples examined by Dr Klein for the Local Government Board could pathogenic germs be discovered. It is true that all the specimens yielded cocci, but in no case could any coli or coli-like bacilli be found. (Supplement to the 30th Report of L. G. B.)

It is also well known that many physicians occasionally order condensed milk for infants with satisfactory results as a temporary 
measure, and certainly with no suspicion that there is any risk of inducing epidemic diarrhoea. Furthermore, an examination of the particular local milk supplies of the Croydon cases did not suggest that any particular dairies had any special incidence, or that distant dairies were more often marked out. Again, Chesterfield with a diarrhoeal rate of 54.4 per 1,000 during the years 1896 to 1899 , derived 98 per cent. of its whole milk supply from cow-sheds situated within the borough or within a radius of five miles.

Therefore though hand-feeding is a very common antecedent of fatal diarrhoea, there is undoubted evidence that breast-fed children do sometimes suffer; there is further an absence of clinical evidence that any large percentage of diarrhoea deaths is due to commercial milk being infective when it reaches the homes. The commonest causes of diarrhoea should therefore be sought in the home or its immediate neighbourhood, though the preponderance of deaths among hand-fed infants shows that infection usually enters the body with the food.

No doubt dirty feeding-bottles may occasionally be infected from dirty milk and subsequently infect future meals, but if this were a common cause of fatal diarrhoea then these fatalities would probably be as common in the country as in the town, seeing that milk, as at present obtained, is probably even more dirty in the country than it is in the town.

It is hardly necessary to point out that there is no difficulty in explaining the infection of breast-fed babies. A few may be directly infected from previous cases, as in the exceedingly interesting series reported by Dr Bruce Low (supplement to Dr Ballard's report, loc. cit.), though this is probably uncommon'. More frequently infection could readily be derived from "matter in the wrong place" for which the human infant has such an astonishing predilection.

\section{Seasonal incidence and meteorological relations.}

It will be seen from Table III. that the well-known preference of summer diarrhoea for the third quarter of the year was marked both in each year and in the decennial average. This characteristic was especially marked in the years of exceptional prevalence.

The exact relations of diarrhoeal deaths in 1901 and 1902 are set forth in Charts I. and II. Unfortunately $4 \mathrm{ft}$. earth tempera-

1 These cases of communicable diarrhoea are probably sui generis-only one of Dr Low's series occurred in the summer quarter. 
tures are not available before 1901. According to Ballard "the rise of diarrhoeal mortality does not commence until the mean temperature recorded by the $4 \mathrm{ft}$. earth thermometer has attained somewhere about $56^{\circ} \mathrm{F}$., no matter what may have been the temperature previously attained by the atmosphere or recorded by the foot earth thermometer. The maximum diarrhoeal mortality of the year is usually observed in the week in which the temperature recorded by the $4 \mathrm{ft}$. earth thermometer attains its mean weekly maximum." Charts I. and II. show marked exceptions to this rule. In 1901 the $4 \mathrm{ft}$. thermometer reached $56^{\circ} \mathrm{F}$. in the $27 \mathrm{th}$ week and attained its maximum in the 30th week. Yet diarrhoea deaths did not occur till the 30th week, and the maximum number of deaths was not registered till the 35th week. This is probably accounted for by the rainfall.

In the 27th week there were two days with good showers, amounting to $: 5$ and 3 inches of rain; and the tendency for the diarrhoea deaths to increase in the 30th week was obviously checked by the five days in that week on which rain fell, while the four days on which rain fell in the 35 th week had a similar effect.

In 1902 Ballard's rules were also departed from, though the relations to rainy days are fairly apparent.

A comparison between 1894 and 1902 is particularly instructive. In the third quarter of 1894 there were only 15 diarrhoeal deaths as compared with 56 in 1902.

Now the mean temperature of the air was very similar, though the diarrhoea mortality was very different. Mr Baldwin Latham has further been good enough to furnish me with figures for the mean monthly temperature of the soil at $2 \frac{1}{2} \mathrm{ft}$. and $5 \mathrm{ft}$. In July and August 1894 both these temperatures were higher than in 1902, though in September 1902 there was about $1^{\circ}$ difference the other way. In 1894 however there were 56 days in the 3rd quarter on which rain fell as compared with only 42 days in 1902 . The total rainfall in the 3rd quarter of 1894 amounted to $8 \cdot 22$ inches, while only 5.50 inches fell in the 3rd quarter of 1902 . Neither the temperature of the air nor the temperature of the soil exhibited anything like this variation. These observations are in favour of Newsholme's contention (Public Health, Vol. XII. p. 163) that rainfall is probably a more important factor than temperature. They also suggest that the relation between diarrhoea and earth temperature is really quite indirect and simply means that the 4 foot thermometer expresses sustained heat modified by the cooling effect of showers. In other words, that the $4 \mathrm{ft}$. 


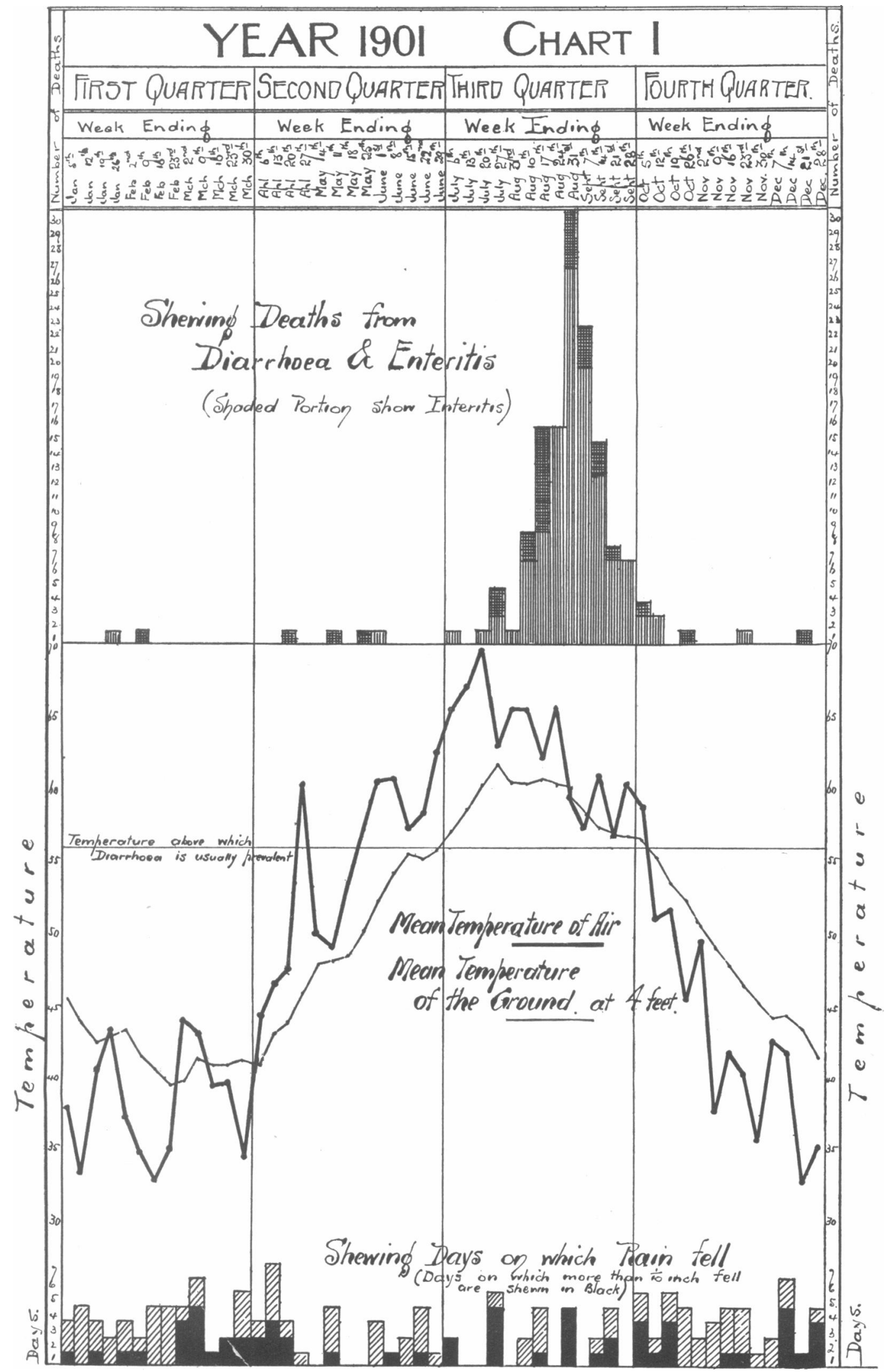




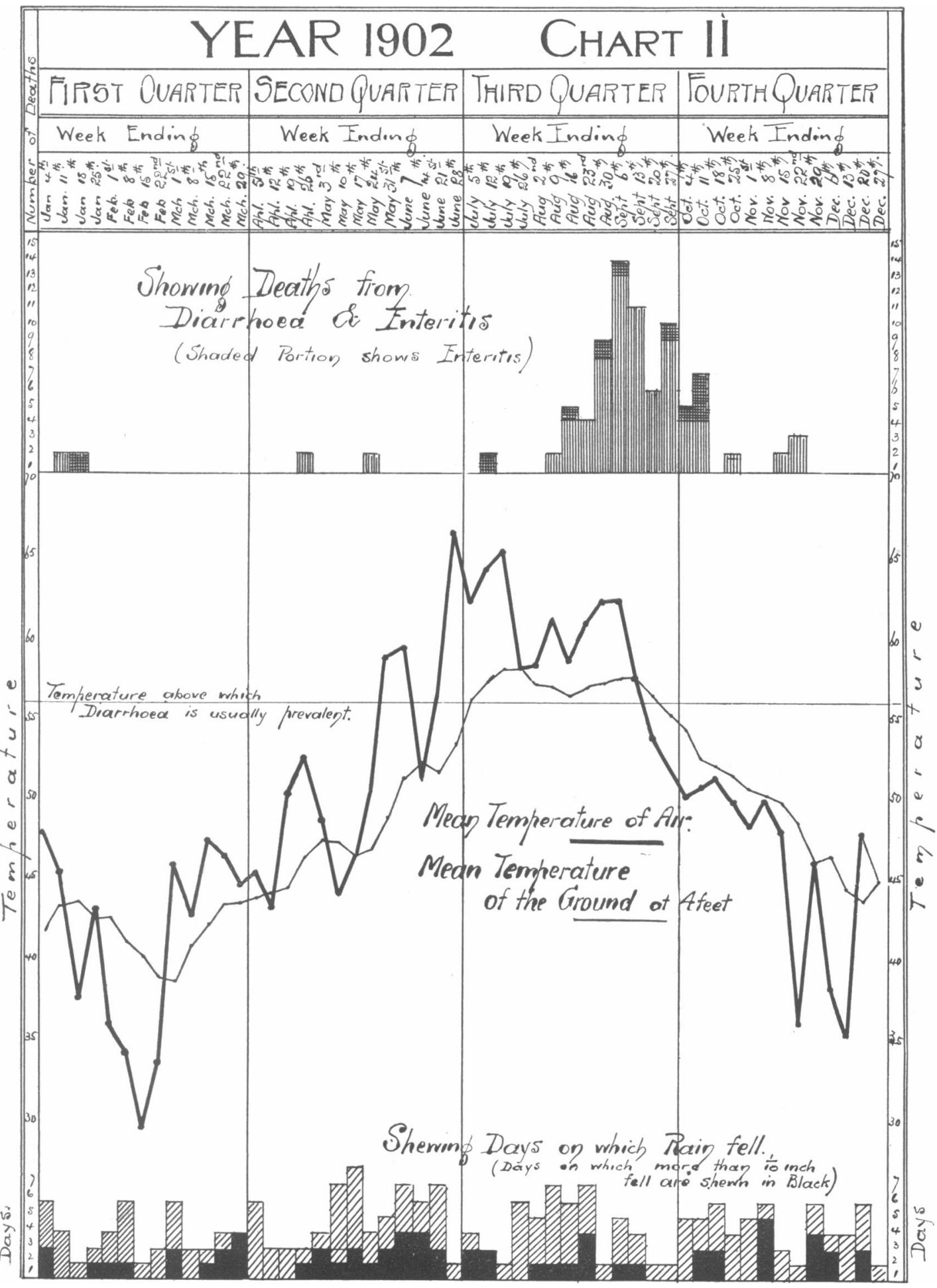


temperature compounds the existing influence of heat with the restraining effect of showers.

Whether this be so or not it is important to remember that in spite of loose talk about chills and the influence of climate per se, neither temperature nor rainfall can be to any appreciable extent the direct cause of fatal diarrhoea, seeing that they are only operative under urban conditions. For instance in the year 1899, though diarrhoea and enteritis were extremely prevalent in Croydon and accounted for $47 \cdot 8$ deaths per 1,000 births, there were only $9 \cdot 3$ deaths per 1,000 births in the neighbouring rural district of Godstone.

The returns for the Croydon Rural District are also of interest, and have been kindly obtained for me by the Medical Officer of Health, Dr C. M. Fegen. The Croydon Rural District is not only "suburban" in situation but in the literal meaning of that word. While much of the district is really rural, some of the townships and especially Mitcham are from a sanitary point of view urban in character. At any rate Mitcham has most of the disadvantages that are inherent to urban life. Now for the 10 years 1893 to 1902 the infantile diarrhoeal mortality in Mitcham was as much as $40 \cdot 2$ per 1,000 births, while the remaining portion of the Croydon Rural District had a rate of only 14.4 per 1,000 births.

\section{Social status as a factor in Causation of Diarrhoea.}

It is notorious that the incidence of fatal diarrhoea is greatest among the infants of the urban poor, though not by any means confined to the residuum.

Of the 974 deaths which occurred in Croydon during the decennium 1893-1902, 955 admitted of classification according to social status. Of these

409 occurred in infants of labourers;

532 occurred in infants of skilled artizans, clerks and tradesmen's assistants ;

14 occurred in infants of the servant-keeping classes.

Why this should be so has not received an entirely adequate explanation.

Employment of mothers is no doubt a factor in some districts, as has been demonstrated in the case of Staffordshire by Dr Reid. But neither in Chesterfield nor in Croydon was this an important 
factor. In Croydon for instance only 17 per cent. of the mothers of infants dying from diarrhoeal diseases were employed from home.

Others suggest that the high diarrhoeal mortality of towns is mainly an expression of lack of care and solicitude on the part of the parents and guardians of infants. No doubt this is to some extent true, as is shown by the high diarrhoeal mortality of illegitimate children. The idle, vicious and intemperate do gravitate to the towns, but diarrhoeal mortality is not limited to this class. Indeed if we neglect the residuum there seems not the least reason to suppose that rural mothers have a monopoly of either maternal affection, energy, thrift or cleanliness. We must therefore admit that the bulk of the difference between urban and rural diarrhoeal mortality is due to the fact that urban conditions render the care of infants, and hand-feeding in particular, more hazardous operations than they would be in rural districts.

There is no absolutely satisfactory way of demonstrating by statistics the share taken by social status in infantile mortality. Probably the best plan would be to draw up life tables for the infants of the "classes" and "masses" in some large town. At present however the necessary materials are wanting. In default the method suggested by Miss Collett, viz. comparison of the number of domestic servants per hundred families, is of value. This may be supplemented by comparison of the proportion of inhabitants occupying tenements of less than five rooms. These figures were therefore specially prepared by the RegistrarGeneral at the recent census for certain wards and sub-districts in the borough.

The diarrhoeal rates for the decenniums are based on the following number of births in the various divisions.

West Ward

South Norwood Ward

South Ward

Central Ward

Thornton Heath Division

East Ward

Upper Norwood Division
11,343

4,714

3,996

3,799

2,994

2,832

1,252 


\begin{tabular}{lcccc}
\multicolumn{5}{c}{ TABLE V. } \\
\multicolumn{1}{c}{$\begin{array}{c}\text { District } \\
\text { Diarrhoeal deaths } \\
\text { per 1000 births } \\
1893-1902\end{array}$} & $\begin{array}{c}\text { Domestic } \\
\text { servants per } \\
100 \text { families }\end{array}$ & $\begin{array}{c}\text { Percentage } \\
\text { occupying less } \\
\text { than 5 rooms }\end{array}$ & $\begin{array}{c}\text { Percentage * } \\
\text { overcrowded }\end{array}$ \\
Upper Norwood & $15 \cdot 1$ & $95 \cdot 8$ & $20 \cdot 3$ & $1 \cdot 73$ \\
South Ward & $23 \cdot 0$ & $46 \cdot 0$ & $19 \cdot 1$ & $2 \cdot 47$ \\
Thornton Heath & $28 \cdot 3$ & $14 \cdot 1$ & $24 \cdot 6$ & $3 \cdot 43$ \\
Central Ward & $28 \cdot 9$ & $36 \cdot 7$ & $20 \cdot 9$ & $2 \cdot 43$ \\
West ", ", & $32 \cdot 6$ & $21 \cdot 7$ & $23 \cdot 4$ & $4 \cdot 52$ \\
East & $37 \cdot 4$ & $49 \cdot 2$ & $13 \cdot 6$ & $0 \cdot 98$ \\
South Norwood Ward & $37 \cdot 7$ & $30 \cdot 5$ & $11 \cdot 6$ & $1 \cdot 17$ \\
Borough & $31 \cdot 1$ & $34 \cdot 3$ & $19 \cdot 3$ & $2 \cdot 74$ \\
& i.e. percentage living more than two to a room. &
\end{tabular}

With regard to overcrowding of persons per room, it will be seen that the above table does not suggest any association of this condition with diarrhoeal deaths. Indeed, as far as can be gathered, diarrhoea is less often associated with overcrowding than are other infantile deaths, as was shown by inquiries at Croydon, where in the case of diarrhoeal deaths only $4 \%$ of the tenements were overcrowded, as compared with $10 \%$ in the case of respiratory and other diseases.

It is evident from Table $\mathrm{V}$. that the variations in the diarrhoeal rates of the different parts of Croydon depend on other factors than the social status of the inhabitants, otherwise it would be impossible to explain why the East Ward with $49 \cdot 2$ servants per hundred families and only 13.6 per cent. of small tenement population should occupy such an inferior position to the Thornton Heath subdivision with only 14. 1 servants per hundred families, and $24 \cdot 6$ per cent. of the population living in small tenements. Nor will social status explain why the South Ward comes off so much better than the East Ward, which as regards both percentage of servants and proportion of small tenement population has the advantage.

Can these anomalies be explained by considering the geological and physiographical difference of the various wards ?

The geology of Croydon. The following brief description has been verified by $\mathrm{Mr}$ W. Whitaker, F.R.S., to whom I am indebted for much information and assistance on this and on many other occasions.

The subsoil in the north of the borough is London Clay, while the Upper Chalk comes to the surface in the south, the Clay and Chalk being separated by a strip of Lower London Tertiaries, comprised of beds of clay, sand, and pebbles. Both the London Clay and Chalk are in parts overlaid by irregularly disposed beds of gravel. 
Taking the wards and subdivisions individually: Upper Norwood subdivision is practically all London Clay with some small superimposed beds of gravel-Thornton Heath subdivision is London Clay with some insignificant exceptions at the southern border including a small uprise of underlying sand near the railway-South Norwood is also London Clay-East Ward is varied, comprising London Clay, Blackheath Beds, Woolwich and Reading Beds, Thanet Sand and Chalk, with some drift gravel near the railway. Physically it varies considerably, clay, gravel, pebbles, sand, and chalk all being present-The Central Ward is almost entirely drift gravel overlying Tertiary Beds and Chalk--The West Ward also is mainly gravel, but with London Clay in its more northern and less built on portions, with an outcrop of Thanet Sand and Chalk at the southern end-The South Ward is largely on the Chalk, but drift gravel is found in the bottom of the valley on either side of the Brighton Road, where the smaller streets are situated, and Thanet Sand in a few streets near Duppas Hill.

Now the generally received opinion seems to be based on Ballard's dicta that solid rock is the least favourable to diarrhoea mortality, and that sandy soil is the most favourable: that clay on the whole is unfavourable, while gravel is favourable or unfavourable according as it approximates to sand or rock. It must be confessed that differences of subsoil do not afford any adequate explanation of the anomalies in the distribution of diarrhoeal mortality which have been already indicated. For instance Thornton Heath has the same subsoil as South Norwood, but a lower diarrhoeal rate in spite of adverse social conditions. The subsoil conditions in the poorer streets are in favour of the East Ward rather than the South Ward, though the diarrhoeal mortality is far lighter in the latter.

\section{Physiography.}

The Physiography of the various wards differs considerably :-

Upper Norwood subdivision is an elevated ridge of London Clay varying from 376 to 220 feet above O.D.; the smaller houses are situated in streets with very good slopes so that rainfall has its maximum effect in cleansing-Thornton Heath subdivision varies in elevation from 236 to 160 feet above O.D. The streets run for the most part down hill so that showers tend to cleanse the roads-South Norwood Ward varies from 200 to 140 feet above O.D.; but the part where diarrhoeal mortality is most marked has no great amount of fall, and what there is is discounted by the fact that the streets are more 
often at right angles to the slope of the hill, and therefore do not benefit as much as they should from. the scouring effects of heavy rain. The level of the subsoil water is very high and often at the surface in wet seasons. Many of the streets are not channelled-The East Ward exhibits physical as well as geological variations, but the poorer parts of the ward are nearly all on the flat with subsoil water near the surface-The West and Central Wards are flat, with little variation in altitude-The South Ward varies considerably in altitude. The poorer streets have for the most part a fair fall in the direction of their length.

It is here I believe that the essential local differences are to be found. Given equal social conditions and similar milk supply, the diarrhoeal mortality will, under equal meteorological conditions, vary with the surface conditions. If the surface contains an undue amount of injurious organic matter diarrhoea mortality will be high. If the surface has been well cleansed by artificial means, or scoured by rainfall, diarrhoea mortality will be low. On this hypothesis we can largely explain the local incidence of fatal diarrhoea in Croydon.

The mortality in the Upper Norwood subdivision is extremely low, not only on account of social conditions but because the poorer streets are to a large extent self-cleansing. This is also aided to some extent by the fact that many of the smaller streets are not thoroughfares and therefore do not suffer from disturbances by extraneous traffic.

Thornton Heath subdivision occupies a comparatively favourable position for a like reason-South Norwood and the low-lying portions of the East Ward come off badly because the roads in the particular parts inculpated are flat, not self-cleansing, and in some cases not properly channelled-The South Ward is better off than the East Ward for precisely opposite reasons. The poorer streets in the South Ward lie high and have good falls. Many of them also are not thoroughfares. In the East Ward on the other hand the poorer streets are almost dead level with the subsoil water very near the surface.

Do these physical advantages apply to the surface generally, or only to the roads?

This is an important practical point which does not appear to admit of an answer at present. $A$ priori it seems difficult to see how the physical advantages of rainfall acting on slopes could be extended to back gardens and unpaved yards, which are often enclosed by walls.

It is very possible that road sanitation is after all the main essential in limiting the toll from diarrhoea in urban districts. 
Other facts in favour of the importance of a dirty soil as a predominant factor in the causation of diarrhoea.

The figures for Croydon Rural District have already been quoted, and those for Mitchan confirm the probable importance of streets and courts which are not self-cleansing. From Dr Fegen's investigations it would appear that infantile diarrhoea deaths in Mitcham are confined to two localities, one on clay subsoil and the other on gravel. While differing from one another in subsoil, however, both agree in having a poor class population on a surface which is that and not selfcleansing or readily cleansed.

Similarly, while Medical Officer of Health for Chesterfield, I was struck with the amazing rise in the diarrhoeal mortality during the years 1897, 1898, and 1899 .

Chesterfield, it must be remarked, is almost entirely a privy midden town and therefore has all the disadvantages incidental to such a system. How very real these are and what an appalling amount of soil pollution results therefrom will hardly be credited by those who have no personal experience of the system. In the process of emptying middens night soil had always to be thrown on to the adjoining surface of either yard or back street. In many cases the excrement had then to be wheeled through an entry into the front street where the contractor would often deposit it in a heap while waiting for the collecting cart. Furthermore there was always more or less spilling of the refuse from wheelbarrows and carts owing to the work being done in the dark.

Now during the three years 1894 to 1896 there were only 51 deaths from diarrhoea in the summer quarter in infants under one year of age as compared with 136 such deaths in 1897 to 1899 . No doubt much of this increased mortality was due to the climatic conditions being more favourable to diarrhoea in the latter period-for instance the summers were certainly drier-but one cannot but also associate the increase with the fact that in 1897 the local Sanitary Authority endeavoured to empty the middens more frequently and there were therefore many more opportunities for polluting the surface of the roads and yards. In 1894 to 1896, 4957 middens were emptied during June to September while 7,831 were emptied during the summer months of 1897 to 1899 . Now the scavenging was at that time done by contractors, with anything but satisfactory results, and it is very suggestive that the rise in diarrhoeal mortality was most marked in that part of the town 
where the work was done with least care and where the flatness of the surface allowed of little self-cleansing. The following are the figures:

\begin{tabular}{lccc} 
& $1894-6$ & $1897-9$ & \multicolumn{2}{c}{ Increase } \\
North & 19 & 43 & 126 per cent. \\
South & 20 & 35 & $75 \quad$, \\
West & 12 & 58 & $383 \quad$,
\end{tabular}

It would be unwise to lay too much stress on these figures, but they certainly suggest that the only cure for the evils incidental to privy middens is wholesale conversion to the water-carriage system. More frequent cleansing may simply aggravate the evil by multiplying opportunities for surface pollution. This conclusion is supported by comparing the diarrhoeal rates for Chesterfield and Ilkeston, two neighbouring towns which are both situated on the coal measures and are very similar in size, industries and social status. From Dr Barwise's valuable report to the Derbyshire County Council for 1900 it would appear that the diarrhoeal rate per 1000 births for the ten years $1891-1900$ was $37 \cdot 7$ in Chesterfield as compared with $17 \cdot 8$ in Ilkeston. Now refuse removal is done at the public expense in Chesterfield but at the expense of the owners in Ilkeston. This means that privy middens would be cleansed much less frequently in Ilkeston than in Chesterfield and that there is therefore less soil pollution of the grosser kind in the former borough.

There is also some reason to believe that diarrhoea is less common in streets and courts where there is no through traffic though this is difficult to prove in default of more exact information as to the distribution of births. At any rate it seems not unlikely, as Dr Waldo suggested, that horse manure may be an important source of soil pollution under favourable conditions.

\section{How does polluted soil affect infants?}

If it be agreed that diarrhoeal mortality has polluted soil for a frequent antecedent, it is still necessary to inquire by what process the human infant is injuriously affected by such a condition. Doubtless organisms capable of infecting infants are present in polluted soil, and these enter the infant's body by the mouth, usually along with the food. How these organisms are carried must still be an open question. Dust and the common house-fly would both be intelligible methods of conveyance. The frequently rapid effect of showers of rain rather 
suggests the dust theory, as flies would rarely be killed by a few showers. The dust theory would also explain the incidence on the smaller streets where the houses are without front gardens and therefore more closely approximated to one of the sources of pollution. Fortunately the point is not of great practical importance, as in either case the removal of organic filth from the neighbourhood of houses is the first essential. When the filth is removed both soil pollution and flies will rapidly diminish. Personally however it is to the good offices of the road surveyor that I look with most interest and hopefulness. When we have roads, paths and passages rendered impermeable and properly swilled with water during the summer months we shall look forward with confidence to a diminution in summer diarrhoea and to increased health in other directions.

Lastly, it is necessary to explain why if diarrhoea is due to polluted roads and yards, it should be-almost limited to the infants of the less affluent. It has already been pointed out that diarrhoea is largely a food infection and almost exclusively an urban phenomenon. It is common in the families of the less affluent for the simple reason that in towns scrupulous cleanliness of the infant's person, nursery, feedingbottles and food is infinitely more difficult than under rural conditions. Scrupulous cleanliness means an expenditure in time and money that the hard-working wife of an artizan can hardly afford, and it is chiefly for this reason that municipal milk depôts appear to meet a want that a simple pure milk supply would not satisfy.

\section{Conclusions.}

(1) That fatal infantile diarrhoea is usually a form of food poisoning.

(2) That infection usually takes place at the home.

(3) That urban conditions are chiefly hazardous from the amount of polluted soil found in the roads and yards of urban districts.

(4) That infinite care is needed if babies are to be hand-fed in towns.

(5) That practical preventive measures should include:

(a) Impermeable roads with efficient channelling.

(b) Copious swilling of roads.

Journ. of Hyg. III 
(c) Education of mothers as to the necessity of scrupulous cleanliness.

(d) The co-operative or municipal provision of specially prepared modified milk which should be sterilized during the diarrhoea season.

(e) A more efficient control of the milk trade with special reference to the provision of cooled, approximately sterile milk from healthy cows.

(f) The provision of houses which shall be sufficiently convenient to allow of their being cleansed with the least possible expenditure of energy. 